\begin{tabular}{|c|c|}
\hline Title & $\begin{array}{l}\text { Value per-recruit analysis of bighand thorny head Sebastolobus macrochir caught off the Pacific coast of northern } \\
\text { Honshu, Japan }\end{array}$ \\
\hline Author(s) & Noranarttragoon, Pavarot; Ueda, Y uji; Hattori, T sutomu; Matsuishi, T akashi \\
\hline Citation & $\begin{array}{l}\text { Fisheries Science, } 77(4), 497-502 \\
\text { https://doi.org/10.1007/\$12562-011-0368-1 }\end{array}$ \\
\hline Issue Date & 2011-07 \\
\hline Doc URL & http:/hdl.handle.net/2115/46844 \\
\hline Rights & $\begin{array}{l}\text { ○ } 2011 \text { 公益社団法人日本水産学会; The final publication is available at www.springerlink.com; @ } 2011 \text { The } \\
\text { Japanese Society of Fisheries Scienc }\end{array}$ \\
\hline Type & article (author version) \\
\hline File Information & FS77-4_497-502.pdf \\
\hline
\end{tabular}

Instructions for use 


\section{Value-per-recruit analysis of bighand thornyhead Sebastolobus macrochir caught off the Pacific coast of northern Honshu, Japan}

Pavarot Noranarttragoon $^{\mathrm{a}}$, Yuji Ueda ${ }^{\mathrm{b}}$, Tsutomu Hattori ${ }^{\mathrm{c}}$, Takashi Matsuishi ${ }^{\mathrm{d} *}$

aAsian Institute of Technology; P.O. Box 4, Klong Luang, Pathum Thani 12120, Thailand

${ }^{\mathrm{b} J a p a n}$ Sea National Fisheries Research Institute, Fisheries Research Agency; Suido-cho, Niigata, 951-8121, Japan

'Hachinohe Station, Tohoku National Fisheries Research Institute, Fisheries Research Agency; Samemachi, Hachinohe, Aomori 031-0841, Japan

$\mathrm{d}^{*}$ Faculty of Fisheries Sciences, Hokkaido University; Minato-cho, Hakodate, Hokkaido 041-8611, Japan

* corresponding author

Tel.: +81 13840 8857; Fax: +81 138408857

E-mail address: correspond_tm@fish.hokudai.ac.jp 


\begin{abstract}
The yield-per-recruit (YPR) analysis has been used to assess growth-overfishing of exploited fish stocks. Since the ex-vessel price per weight widely depends on the size of the fish, the result of the YPR does not imply the revenue. The value-per-recruit (VPR) analysis, which is an economic expansion of the YPR analysis, was conducted to bighand thornyhead Sebastolobus macrochir caught off Pacific coast of northern Honshu, Japan. The results showed that, under the current age at first capture ( $t_{c}=3$ ), the current fishing mortality ( $F=0.12$ ) was close to optimum level. However, under the current $F$, optimum $t_{c}$ in the VPR model was 8 years and would lead to a $47 \%$ increase compared to the current revenue. The maximum YPR was obtained at $t_{c}=6$ years, but the revenue at $t_{c}=6$ only gave a $20 \%$ increase in the maximum revenue. The difference was caused by the size dependency of the ex-vessel price per weight. The VPR model would generate fisheries management plans with both economical and biological consideration, and would help in making general consensus of fisheries management strategies.
\end{abstract}

Keywords: Bio-economic model, Fisheries management, Sebastolobus macrochir, Value-per-recruit, Yield-per-recruit 


\section{Introduction}

The rapid development of fisheries around the world has resulted in intensive exploitation of resources [1-4]. For most of the open accessed stock, fisheries have caught small sized fish rather than the optimal size, resulting in the condition of growth overfishing [5,6]. Some papers have revealed the huge economic losses of growth overfishing [5,7]. Growth overfishing is not only ineffective stock usage, but also leads to recruit overfishing from the depletion of spawning stock, accelerating the depletion of the stock [4].

Generally, the yield-per-recruit (YPR) model [8] has been used to assess growth overfishing. The model estimates the yield per recruit for various fisheries activities (fishing mortality and fish size), describes the current usage of the stock, and suggests policies to enhance the yield. YPR analysis focuses only on yield and does not consider economic aspects. The ex-vessel price per weight increases with the fish size $[9,10]$; thus, catching larger fish would lead to more economic benefits than increasing yield. Because the main objective of fishers is often to maximize revenues rather than maximize landing weight [11], an economic aspect should be built into fisheries management models.

As an economical extension of the YPR model, Hayashi and Hasegawa [12] proposed the value isopleths diagram and applied it to a prawn fishery in 1968. The same idea has been mentioned as value-per-recruit (VPR) model [13], utility-per-recruit model (U/R) [14, 15], or revenue-per-recruit (RPR) model [16, 17]. These ideas have been appeared without citations, would be developed independently and were not widely applied for fishery management. Since these analyses directly quantify the economic merits of the fishery regulation and, in most of the cases, the result had wide differences to the result of YPR analysis, these analysis should be of more interest to managers and fishers [15].

The bighand thornyhead Sebastolobus macrochir is a high-priced fishery resource, and is an important target species for small-sized and medium-sized trawl fisheries caught off the Pacific coast of northern Honshu, Japan [18,19](Fig. 1) . The species has a slow growth rate and a long lifespan [20]. Fig. 2 shows the catch of the species caught in this area, and the fishing effort of the bull trawl in Iwate prefecture which is the main gear for this species. The catch of the species in this area has declined from 3,585t in 1975 to 259t in 1999. However the decline of the fishing effort has been 
largely delayed maybe because of the high price of the fish. The length composition of this species in 2005 was shown in Fig. 3 and the mode was around $9 \mathrm{~cm}$ which is much smaller than the length at female first maturity (ca. $15 \mathrm{~cm}$ ) [20]. It was partly because of the better recruit occurred in 1999 to 2002 but it reveals the demand and ability of the small fish fishery for the species. To avoid the growth overfishing and to enhance the proper use of this stock, the fishery regulation for the small fish fishery was considered. Since this species has a large ex-vessel price dependency on fish size (see result), the economic merits of the small fish fishery regulation is expected to be much larger than that implied by YPR analysis.

In this study, biological and economic data of bighand thornyhead Sebastolobus macrochir caught off the Pacific coast of Northern Honshu, Japan was analysed by the VPR (Value-per-recruit) model as well as the YPR (Yield-per recruit) model, to describe the current fishery situation and to forecast the economic effect of fisheries management.

\section{Materials and methods}

Yield-per-recruit Model

Because the VPR model used in this study is an expansion of the traditional YPR model [8], we briefly describe the YPR model.

YPR can be described as

$$
Y P R=\frac{1}{R} \int_{t_{\mathrm{c}}}^{t_{\max }} F N_{t} w_{t} d t
$$

where $F$ is the fishing mortality, $w_{t}$ is the weight of a fish at age $t$, and $t_{\mathrm{c}}$ is the age at first capture.

$t_{\max }$ is the maximum age and $R$ is the number of fish at the age at recruitment $t_{\mathrm{r}} . N_{t}$ is the number of fish at age $t$ and is described as

$$
N_{t}= \begin{cases}R \exp \left[-M\left(t-t_{\mathrm{r}}\right)\right] & ; t_{\mathrm{r}} \leq t<t_{\mathrm{c}} \\ R \exp \left[-M\left(t_{\mathrm{c}}-t_{\mathrm{r}}\right)-(F+M)\left(t-t_{\mathrm{c}}\right)\right] & ; t \geq t_{\mathrm{c}}\end{cases}
$$


Combining this equation with von Bertalanffy's growth curve, YPR can be calculated as

$$
Y P R=F W_{\infty} \exp \left[-M\left(t_{\mathrm{c}}-t_{\mathrm{r}}\right)\right] \sum_{n=0}^{3} \frac{U_{n} \exp \left[-n K\left(t_{\mathrm{c}}-t_{0}\right)\right]}{F+M+n K}
$$

where $W_{\infty}, K$, and $t_{0}$ are the parameters of von Bertalanffy's growth curve. $M$ is the natural mortality and $U_{n}$ is the summation parameter $\left(U_{0}=1, U_{1}=-3, U_{2}=3, U_{3}=-1\right)$.

For the numerical calculation, this equation can be converted into a discrete form as

$$
Y P R=\frac{1}{R} \sum_{a=t_{\mathrm{c}}}^{t_{\max }} w_{a}^{\prime} \frac{F}{F+M}[1-\exp (-F+M)] N_{a}
$$

where $w_{a}^{\prime}$ is the weight of a fish at age $a+0.5$, which is an approximation of the average at age $a$ (from exactly age $a$ to just before age $a+1$ ).

\section{Value-per-recruit Model}

The VPR is described as

$$
V P R=\frac{1}{R} \int_{t_{c}}^{t_{\max }} p_{t} F N_{t} d t
$$

where $p_{t}$ is ex-vessel price per fish at age $t$ and the other notations are same as the YPR model described above. This model is equivalent to Hayashi and Hasegawa [12].

For the numerical calculation, this equation can be converted into a discrete form as

$$
V P R=\frac{1}{R} \sum_{a=t_{c}}^{t_{\max }} p_{a}^{\prime} \frac{F}{F+M}[1-\exp (-F+M)] N_{a}
$$

where $p_{a}^{\prime}$ is the ex-vessel price of fish at age $a+0.5$, which is an approximation of the average at age $a$ (from exactly age $a$ to just before age $a+1)$.

Ex-vessel price 
The relationship between body size and ex-vessel price used in the VPR model was obtained from the recorded data from January 2004 to March 2005 from small-sized and medium-sized trawlers at Hachinohe fishing port which is one of the main port for this species in the Pacific coast of northern Honshu, Japan.

The ex-vessel price data contained the catch in weight $(\mathrm{kg})$ and the price (Japanese yen, JPY) for the size categories. The categories were defined as number of fish per box. A total of 1,668 ex-vessel price data was used to the analysis.

The body sizes for categories were derived from the measurement data of Hachinohe Station, Tohoku National Fisheries Research Institute, Fisheries Research Agency. The data were composed from the mean standard length (mm) for categories from " 10 ” to " 80 ”, which represent the number of fish per box.

To estimate the weight of a fish in each category, a logarithmic function was fitted to the total weight of the box and the number of fish per box based on the data from 1995 to 2004. Then the otal weight per box is described as

$$
Z=1264.8 \ln (X)+1858.8
$$

where $Z$ is the total weight per box ( $\mathrm{g}$ ) and $X$ is the number of fish per box $\left(n=14, r^{2}=0.9957, P<\right.$ 0.001). From this equation, the average weight of a fish in each category was estimated as $Z / X$.

Then, the ex-vessel price per fish at a given weight was plotted and fitted to the Gompertz curve [21].

$$
p=\alpha \exp [-\beta \exp (-\gamma w)]
$$

where $p$ is the ex-vessel price per fish (JPY) and $w$ is the weight per fish (g). Constant parameters $\alpha$, $\beta$, and $\gamma$ were estimated by fitting the ex-vessel price per weight and the curve given in Eq. (8) by minimizing the sum of square residuals by using the nonlinear least square method (Table 1).

Von Bertalanffy's weight growth curve is described as follows

$$
w_{t}=W_{\infty}\left\{1-\exp \left[-K\left(t-t_{0}\right)\right]\right\}^{3}
$$

Table 1 lists the reported parameters [20]. Although the longevity of bighand thornyhead is reported to be at least 20 years [20], it is likely longer because the estimated longevity of the shortspine 
thornyhead, a species related to bighand thornyhead, is 40 years [22]. Thus, $t_{\max }$ was set to 40 (Table 1).

The average ex-vessel price per fish at age $a\left(p_{a}^{\prime}\right)$ was calculated by combining the ex-vessel price at a given weight (Eq. 10) with the growth curve (Eq. 11) as

$$
\begin{aligned}
& p_{a}^{\prime}=\alpha \exp \left[-\beta \exp \left(-w_{a+0.5}\right)\right] \\
& w_{a+0.5}=W_{\infty}\left\{1-\exp \left[-K\left(a+0.5-t_{0}\right)\right]\right\}^{3}
\end{aligned}
$$

The estimated weight and ex-vessel price were shown in Fig. 4.

The current fishing mortality was set at 0.12 year derived from the average of the fishing mortality from 2005 to 2007 [20]. The current age at first capture was 3 years from the length composition of the catch [20].

\section{Results}

Fig. 5 shows the contours of YPR and VPR. At the current fishing mortality $F=0.12$, the YPR was 89.6(g/recuit), while VPR assessment showed that the VPR of the stock was 79.1 (JPY/recruit) (Fig. 5). At the current age at first capture, YPR and VPR were maximized at $F=0.16$ and 0.10 , and the maximized YPR and VPR were 91.3 and 79.6 respectively (Fig. 6a). Both models suggested that the level of fishing mortality under the current age at first capture gave almost the optimum revenue and yield.

However, the revenue from the stock could potentially be increased. When the fishing mortality was fixed at $F=0.12$, the maximum VPR (116.3 JPY/recruit) was obtained at $t_{c}=8$ years (Fig. 6b). This would lead to a 47\% increase compared to the current revenue. The maximum YPR (101.2 g/recruit) was obtained at $t_{c}=6$ years, but the revenue at $t_{c}=6$ (107.3 JPY/recruit) only gave a 20\% increase in the maximum revenue.

\section{Discussion}


In the situation where small fish fisheries leads to growth overfishing, changing the target fish size should be an urgent task for the fisheries management. To enhance fisheries management, tools to forecast revenue would be helpful. Additionally, the forecast results should be a strong incentive for fishers to support fishery regulations. Through the application of the VPR model to the bighand thornyhead stock, scientific advice based on VPR would meet the needs of fisheries management and be more informative than the advice based purely on biological analysis.

The results of the VPR and YPR models differ; the VPR model indicated that optimum age at first capture $t_{\mathrm{c}}$ is age 8 years, whereas that for the YPR model is 6 years using the current fishing mortality $F=0.12$

Regarding the current situation of the fishery, increasing the age at first capture by changing the gear selectivity of fish length may encounter difficulties. Fish are mainly caught by trawl gears, which simultaneously target multiple species. The selectivity of the gears can not be set to optimize the commercial fish size of bighand thornyhead. However, if fishers use their experience to identify fishing grounds, they could select fishing grounds for larger fish, which would increase their yield or revenue.

If both fishing mortality and age at first capture could be increased from current fishing mortality, YPR and VPR would increase. Theoretically, YPR and VPR were maximized at $F=\infty$, but excess fishing effort leads decrease of the spawning stock biomass and recruit over fishing, which is not appear in the YPR and VPR analysis. For considering the increase of the fishing mortality, it is recommended that spawning-per-recruit (SPR) analysis [23] would be conducted adding to the YPR and VPR analysis.

Although several factors influences fish price, the current study focuses on the effect of size. Fish size dependency of the ex-vessel price is the rules rather than the exception in fisheries [10]. With regard to the bighand thornyhead stock, the ex-vessel price per kilogram is higher for larger fish. For example, the ex-vessel price per fish for the large fish category (10 fish per box) is 10 times higher than the small fish category (60 fish per box). 
Generally, the fish price often depends on the landing weight [9]. However, the current study ignored the effect of landing weight on ex-vessel price because the production of the stock was quite stable in 2000-2005 and the variation of YPR was less than 10\% from $t_{c}=3$ to 9 years at the current fishing mortality $F=0.12$. However, the current model could be expanded to consider the effects of landing weight on ex-vessel price.

In conclusion, this paper demonstrates that the VPR model, originally proposed by Hayashi and Hasegawa [12], provides a tool for fisheries management through the use of stock assessment data and ex-vessel price information available from the monitoring program. Although the model is simple in form, it allows biological and economic information for fisheries management to be estimated. The VPR model provides fishery managers information for policy formulation, which they can transform into a management plan. However, further research should be conducted to develop a more sophisticated model that includes the influence of landing weight on ex-vessel price.

The exploitation of bighand thornyhead caught off the Pacific coast of northern Honshu was close to the optimal level considering both biological and economic consequences using the current selectivity for fisheries. However, there is potential to increase the revenue up to $47 \%$ if the selectivity could be changed to the optimum age at first capture $t_{c}=8$ years.

\section{Acknowledgments}

This work was conducted while the first author was visiting Hokkaido University with support from JSPS’s “Fostering Program for Young and Female Researchers in Sustainable Fisheries Sciences in Southeast Asia”. We are grateful to the students in the laboratory of fish population dynamics, Hokkaido University for their assistance in translating the Japanese reference articles.

\section{References}


1. FAO (2009) The state of world fisheries and aquaculture 2008. Food and Agriculture Organization of the United Nations, Rome

2. Heazle M, Butcher JG (2007) Fisheries depletion and the state in Indonesia: towards a regional regulatory regime. Mar Policy 31:276-286

3. Jackson JBC, Kirby MX, Berger WH, Bjorndal KA, Botsford LW, Bourque BJ, Bradbury RH, Cooke R, Erlandson J, Estes JA, Hughes TP, Kidwell S, Lange CB, Lenihan HS, Pandolfi JM, Peterson CH, Steneck RS, Tegner MJ, Warner RR (2001) Historical over-fishing and the recent collapse of coastal ecosystems. Science 293:629-638

4. Stobutzki IC, Silvestre GT, Abu Talib A, Krongprom A, Supongpan M, Khemakorn P, Armada N, Garces LR (2006) Decline of demersal coastal fisheries resources in three developing Asian countries. Fish Res 78:130-142

5. Najmudeen TM, Sathiadhas R (2008) Economic impact of juvenile fishing in a tropical multi-gear multi-species fishery. Fish Res 92:322-332

6. Marchal P (1997) Managing growth overfishing with multiannual compromise strategies. Can J Fish Aquat Sci 54:2255-2276

7. Noranarttragoon P (2007) An evaluation on economic losses from luring purse seine fishery in the Gulf of Thailand. Kasetsart J (Nat Sci) 41:141-148

8. Beverton RJH, Holt SJ (1957) On the dynamics of exploited fish populations. Chapman and Hall, London

9. Gates JM (1974) Demand price, fish size and the price of fish. Can J Agr Econ 22:1-12

10. Hilborn R, Walters CJ (1992) Quantitative fisheries stock assessment: choice, dynamics and uncertainty. Chapman and Hall, London

11. Lindebo E, Hoff A, Vestergaard N (2007) Revenue-based capacity utilization measures and decomposition: The case of Danish North Sea trawlers. Eur J Oper Res 180:215-227 
12. Hayashi T, Hasegawa A (1968) Some discussions on the stock utilization and fishery management. Rep Conference Fish Agency Jap Gov Fish Resources Invest 8: 63-74 (in Japanese)

13. Ye Y (1998) Assessing effects of closed seasons in tropical and subtropical penaeid shrimp fisheries using a length-based yield-per-recuit model. ICES J Mar Sci 55:1112-1124

14. Die DJ, Restrepo VR, Hoenig JM (1988) Utility-per-recruit modelling: a neglected concept. Trans Am Fish Soc 117:274-281

15. Hart DR (2001) Individual-based yield-per-recruit analysis, with an application to the Atlantic sea scallop, Placopecten magellanicus. Can J Fish Aquat Sci 58:2351-2358

16. Gallagher CM, Hannah RW, Sylvia G (2004) A comparison of yield per recruit and revenue per recruit models for the Oregon ocean shrimp, Pandalus jordani, fishery. Fish Res 66:71-84

17. Katsukawa T (2005) Evaluation of current and alternative fisheries management scenarios based on spawning-per-recuit(SPR), revenue-per-recruit(RPR), and yield-per-recruit(YPR) diagrams. ICES J Mar Sci 62:841-846

18. Kitagawa D, Hashimoto J, Ueno Y, Ishida K, Iwakiri J (1985). Distribution property of the kichiji rockfish (Scorpaenidae) in the deep sea region off Sanriku. In: JAMSTEC(eds) JAMSTECTR Deepsea Research, Kanagawa, pp.107-117

19. Watanabe T, Watanabe K, Kitagawa D (2004) Density and spatial distribution of kichiji rockfish Sebastolobus macrochir estimated with a deep-sea video monitoring system on a towed sledge. JARQ 38:129-135

20. Hattori T, Ito M, Narimatsu Y, Okuda T (2010) Stock assessment and evaluation for bighand thornyhead Sebastolobus macrochir off the Pacific coast of northern Japan (fiscal year 2009). In: Fisheries Agency and Fisheries Research Agency of Japan(eds) Marine fisheries stock assessment and evaluation for Japanese waters, Tokyo, pp. 922-947 (in Japanese)

21. Winsor CP (1932) The Gomperz curve as a growth curve. Proc Nat Acad Sci 18:1-8

22. Pacific Fishery Management Council (2008) Pacific coast groundfish fishery stock assessment and fishery evaluation 1. Pacific Fishery Management Council, Portland

23. Prager MH, O’Brien JF, Saila SB (1987) Using lifetime fecundity to compare management strategies: a case history for striped bass. N Am J Fish Manag 7:403-409 


\section{Figure Captions}

Fig. 1 Study area of bighand thornyhead Sebastolobus macrochir

Fig. 2 Total catch of bighand thornyhead caught by Japanese fishers off the Pacific coast of northern Honshu, Japan, and fishing effort (number of haul catching bighand thornyhead) of bull trawl fisheries at Iwate Prefecture, Japan [20]

Fig. 3 Length frequency of the bighand thornyhead caught off the Pacific coast of northern Honshu, Japan

Fig. 4 The weight and price curve of bighand thornyhead. Weight curve was calculated from von Bertalanffy's growth curve with parameters from Hattori et al. [15] Price curve is a Gompertz curve fitted to the observed ex-vessel price at Hachinohe Minato fishery market from January 2004 to March 2005

Fig. 5 Contours describing the response of (a) yield-per-recruit and (b) value-per-recruit to different fishing mortality $F$ and age at first capture $t_{c}$ for bighand thornyhead caught off the Pacific coast of northern Honshu, Japan. Solid circles represent the current fishing mortality and age at first capture. Broken lines represent current fishing mortality $(F=0.12)$ or age at first capture $\left(t_{\mathrm{c}}=3\right)$

Fig. 6 VPR (solid lines) and YPR (broken lines) expected at (a) current age at first capture $\left(t_{\mathrm{c}}=3\right.$ ) and (b) current fishing mortality $(F=0.12$ ) for bighand thornyhead caught off the Pacific coast of northern Honshu, Japan 


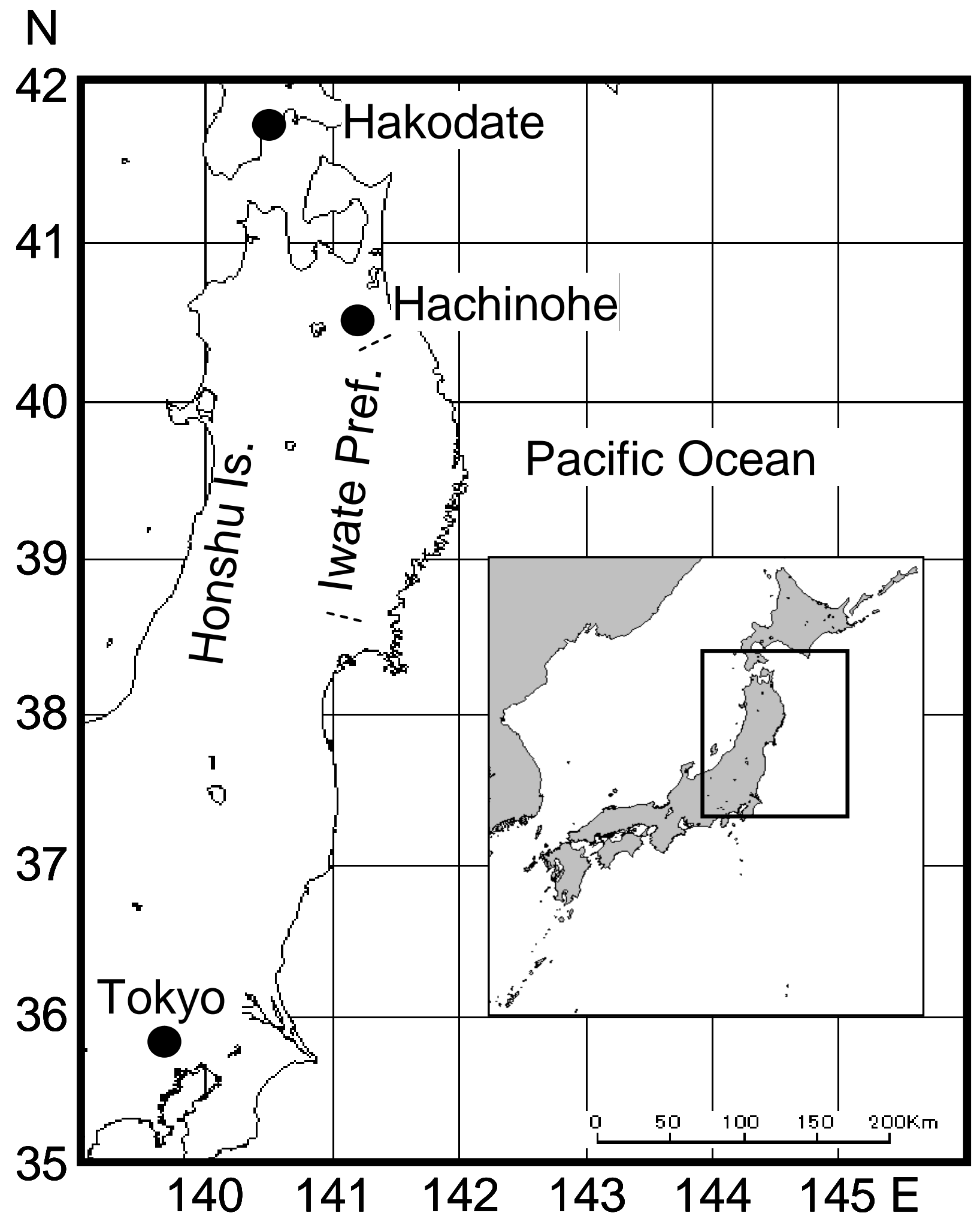

Fig. 1 


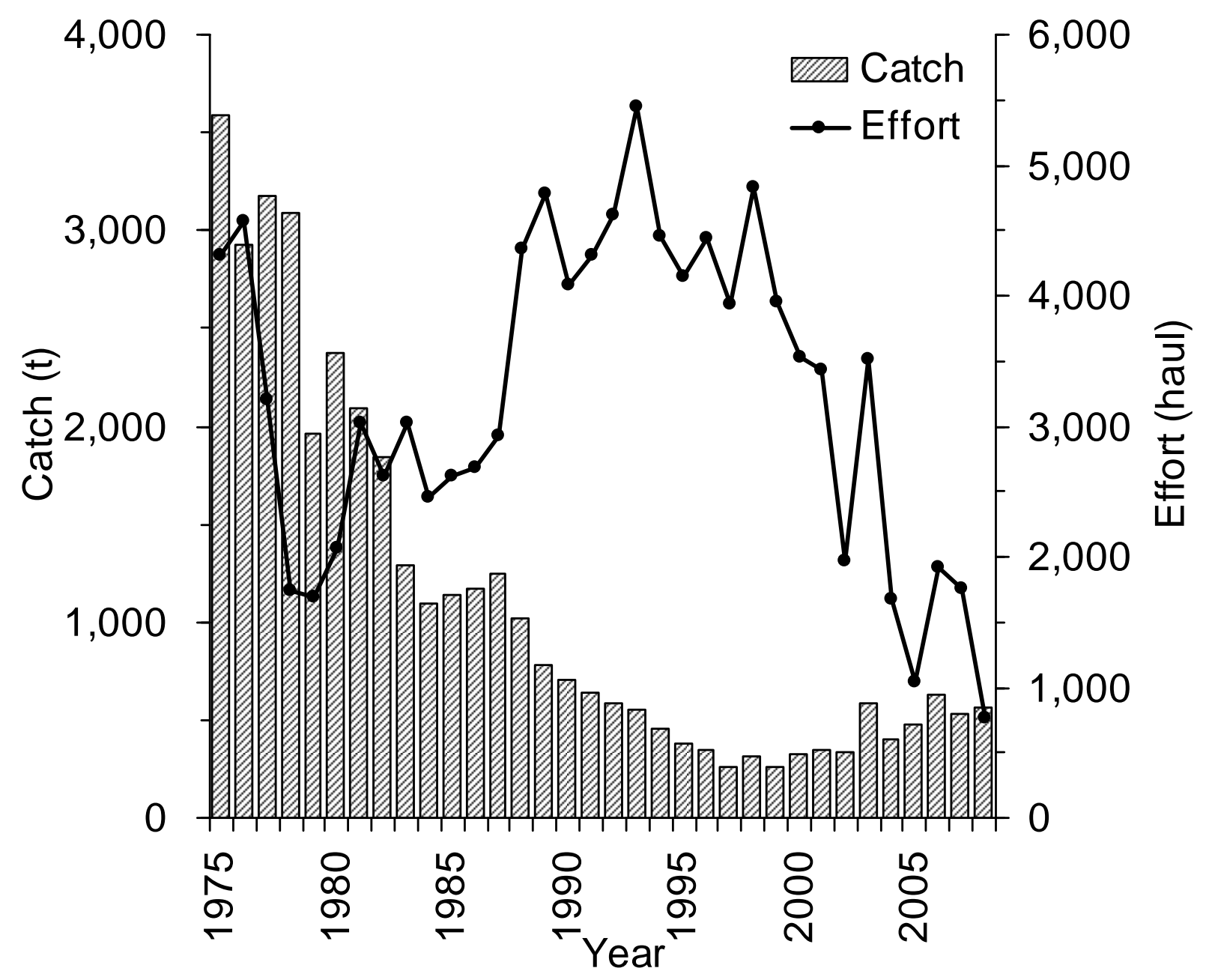

Fig. 2 


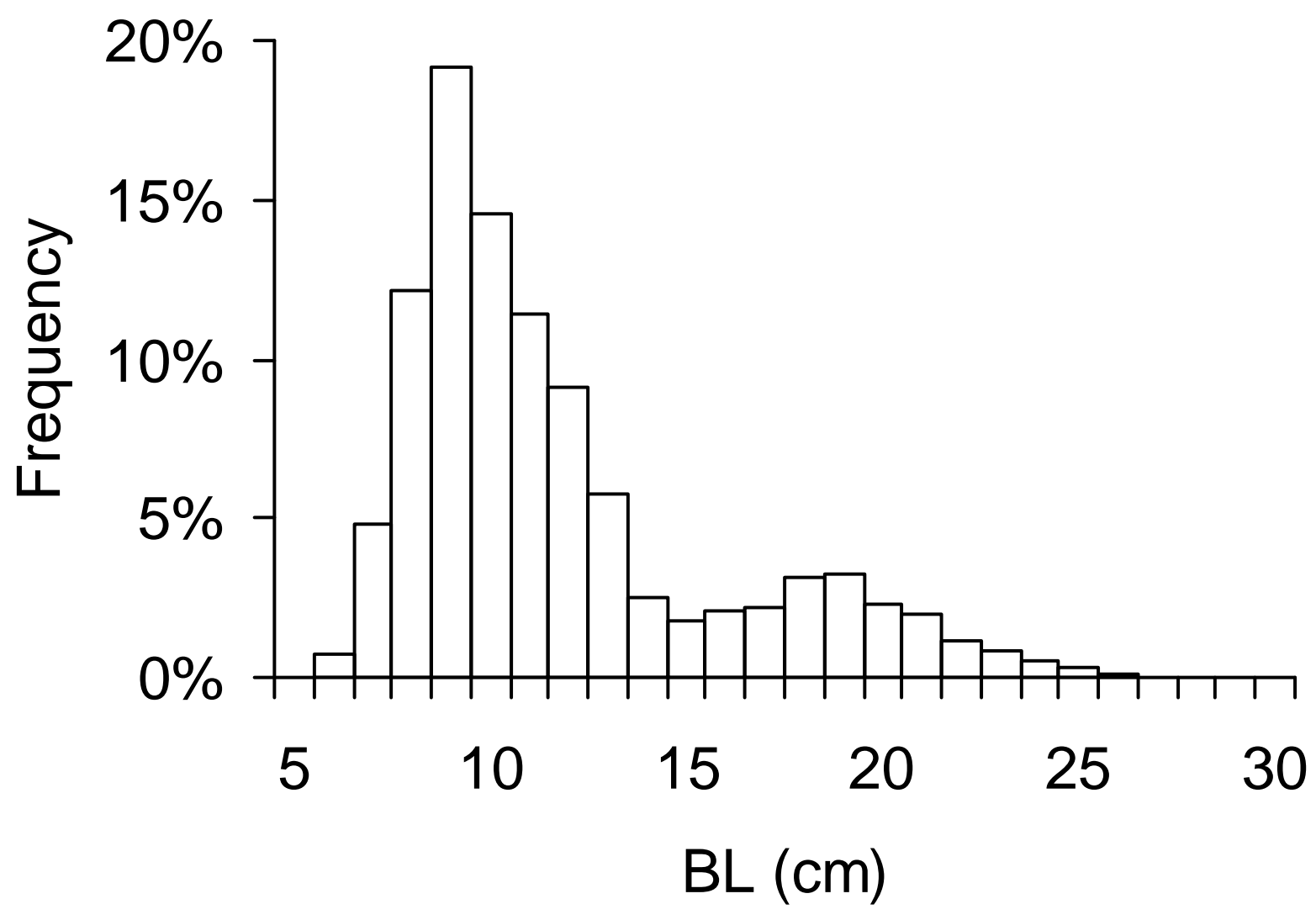

Fig. 3 


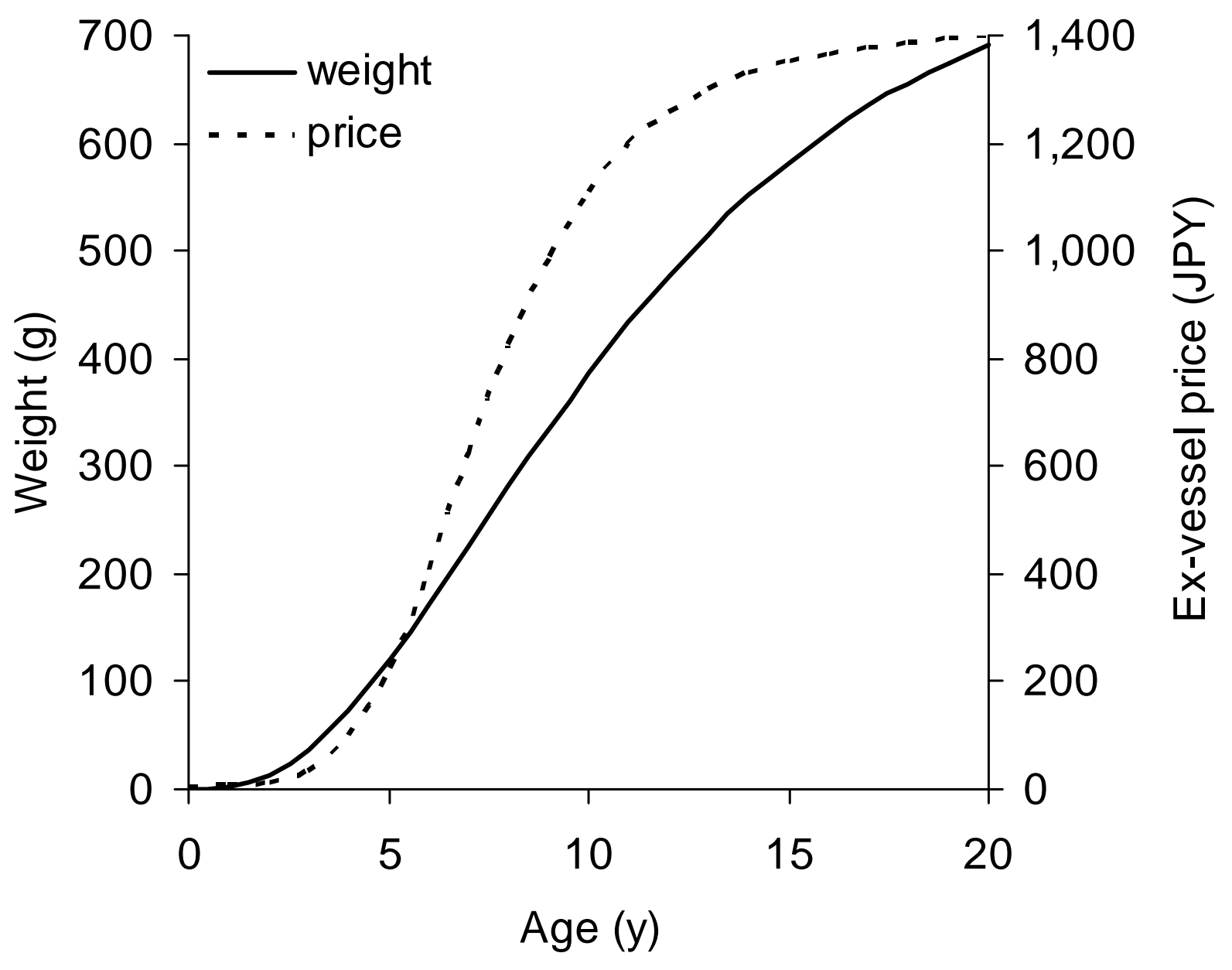

Fig. 4 

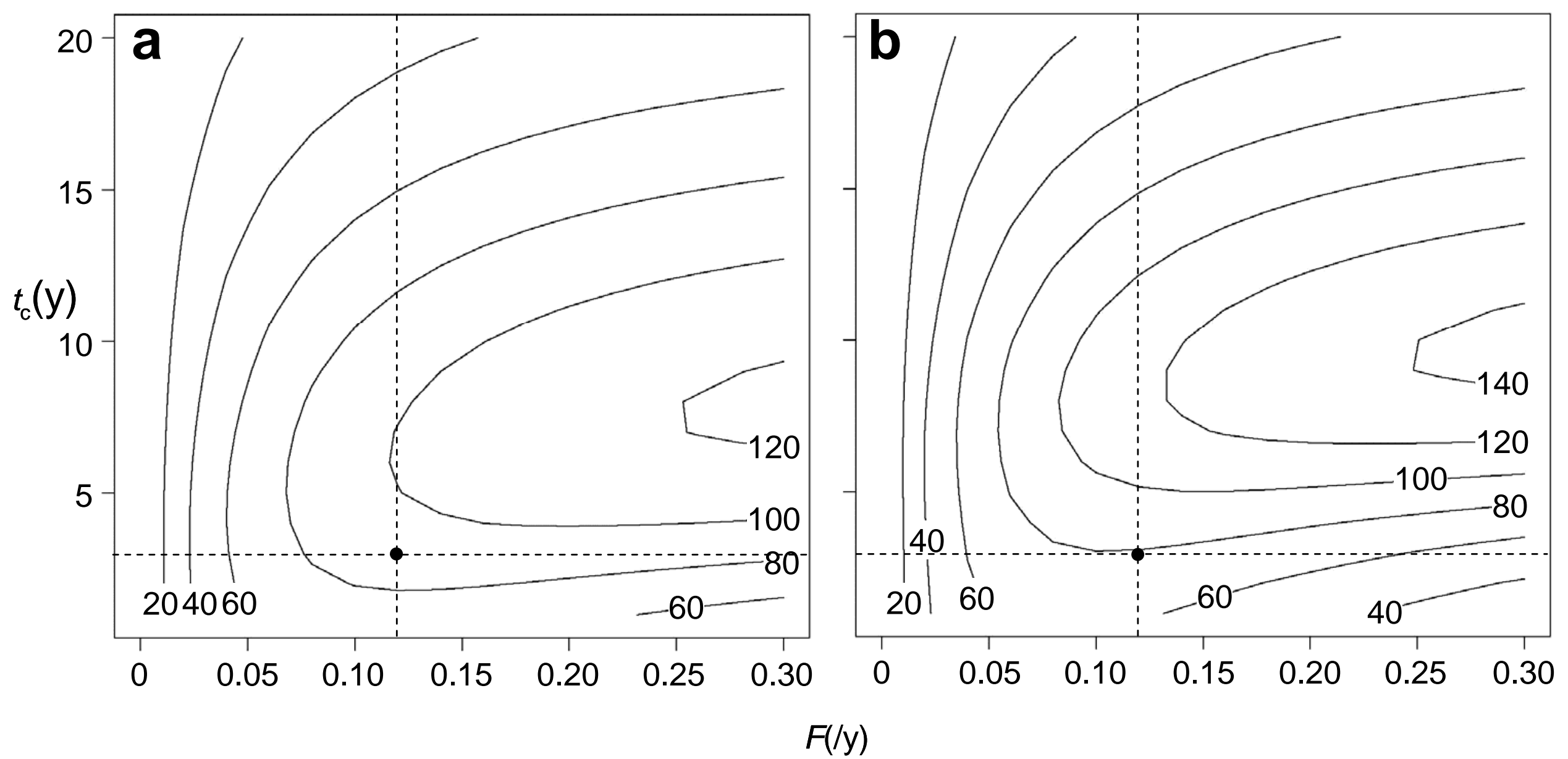

Fig. 5 

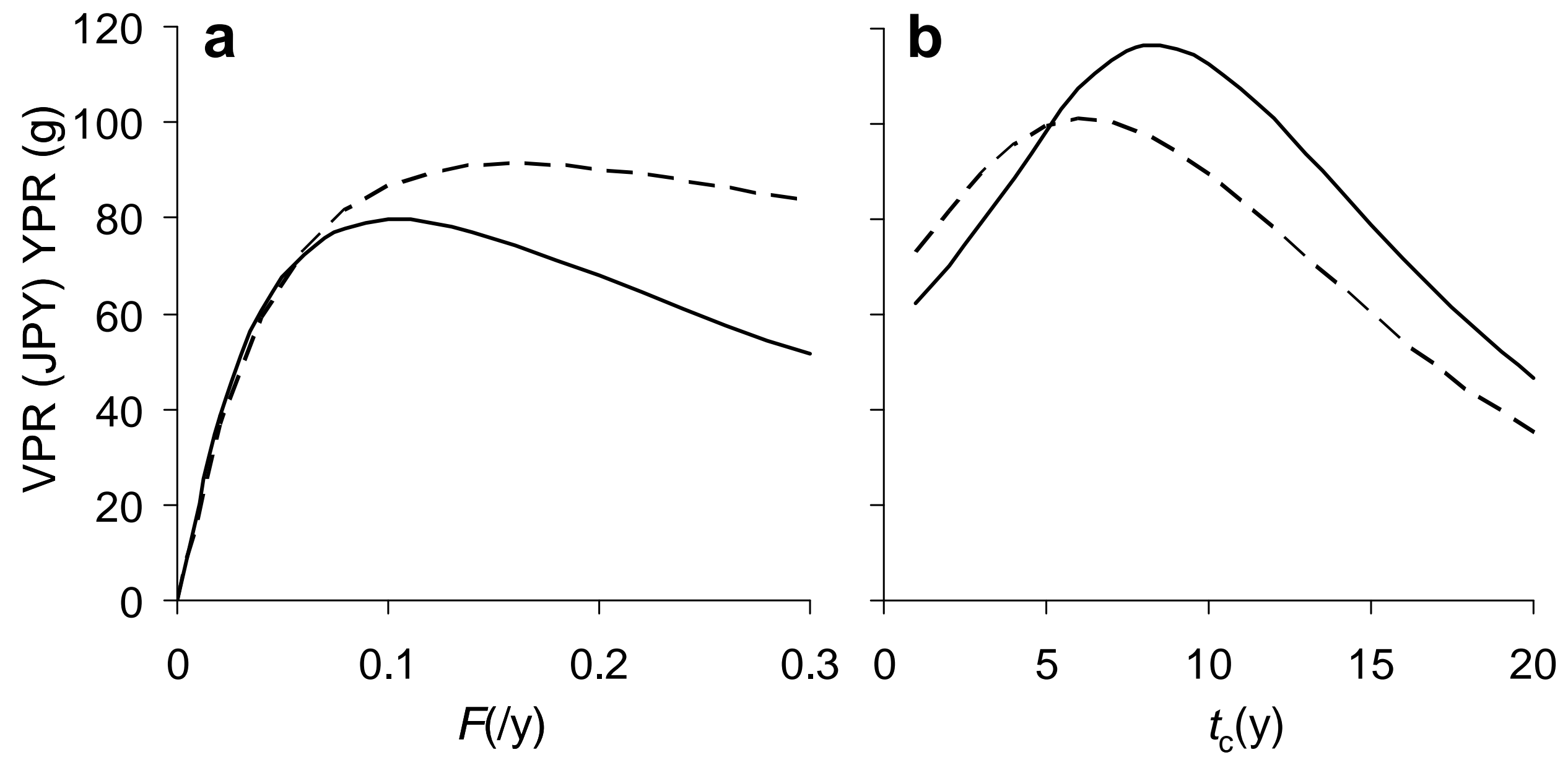

Fig. 6 
Table 1 Parameter values used in the VPR and YPR models for bighand thornyhead Sebastolobus macrochir on the northeast coast of Honshu, Japan

\begin{tabular}{ll}
\hline Parameter & Value \\
\hline$t_{r}$ & $1.0 \mathrm{yr}^{\mathrm{a}}$ \\
$t_{\max }$ & $40^{\mathrm{b}}$ \\
$M$ & $0.125 / \mathrm{yr}^{\mathrm{a}}$ \\
$W_{\infty}$ & $789.47 \mathrm{~g}^{\mathrm{c}}$ \\
$K$ & $0.158 / \mathrm{yr}^{\mathrm{d}}$ \\
$t_{0}$ & $0.185 \mathrm{yr}^{\mathrm{d}}$ \\
$\alpha$ & $1445.1^{\mathrm{e}}$ \\
$\beta$ & $5.463^{\mathrm{e}}$ \\
$\gamma$ & $0.007379^{\mathrm{e}}$ \\
\hline
\end{tabular}

${ }^{\text {a }}$ Life history information[20]

${ }^{\mathrm{b}}$ Inferred from Hattori et al.[20] and Pacific Fishery Management Council[22] (see text)

${ }^{\mathrm{c}}$ Converted from an allometric length-weight relationship [20]

${ }^{\mathrm{d}}$ Growth curve [20]

${ }^{\text {e }}$ Price curve parameters fitted to the data (see text) 
東北地方太平洋岸沖のキチジの VPR 解析

パヴァロット・ノラナットラグーン(AIT)、上田祐司(日水研)、服部努(東北水研八戸)、松石 隆 (北大院水)

成長乱獲診断に広く用いられている YPR 解析を拡張し、単価のサイズ依存を考慮した VPR 解 析を、東北海域で漁獲されたキチジのデータに対して行った。その結果、現状の漁獲開始年齢 $\left(t_{c}=3\right.$ 歳 $)$ では、現状の漁獲係数 $(F=0.12)$ は、最適な YPR や VPR を概数達成しているが、現状の $F$ を維持した場合、最適な $t_{c}$ はVPR 解析と YPR 解析で、それぞれ 8 歳と 6 歳、またその時の収 入の増加はそれぞれ 47\%と 20\%となり、結果の差異が明らかになった。VPR 解析が資源管理に おける合意形成に寄与寸ることが期待される。 